\title{
PERBANDINGAN PERSEPSI KHALAYAK ANTARA IKLAN YANG MENGANDUNG HUMOR DAN TIDAK MENGANDUNG HUMOR
}

\author{
Ira Yuni Mirandha ${ }^{1}$ dan Adi Bayu Mahadian² \\ ${ }^{1,2}$ Universitas Telkom
}

\begin{abstract}
ABSTRAK
Periklanan menjadi salah satu komponen penting dalam komunikasi pemasaran. Sebuah iklan akan dipersepsi oleh alam pikir melalui berbagai tahapan. Berupaya menarik perhatian konsumen, pengiklan menyisipkan unsur humor yang identik dengan segala sesuatu yang membuat tertawa dan lucu, yang dijadikan salah satu daya tarik pesan dalam iklan. Penulis ingin melihat perbedaan alam pikir audience dalam mempersepsi antara iklan mengandung humor dan tidak mengandung humor. Untuk itu diperbandingkan iklan mengandung humor, Ramayana Department Store dan iklan tidak mengandung humor, Matahari Department Store. Dalam penelitian ini, bertujuan untuk mengetahui adakah perbedaan persepsi audience antara iklan yang mengandung unsur humor dan tidak mengandung unsur humor. Dalam mencapai tujuan penelitian, penulis menggunakan metode kuantitatif agar mendapat pemahaman yang sistematis dan objektif. Dengan menggunakan persepsi selektif Belch dan Belch berdasarkan empat tahap proses persepsi antara lain: terpaan, perhatian, pemahaman dan ingatan terhadap iklan. Dari hasil penelitian, persepsi audience terhadap pemeran iklan, latar dalam iklan, rangkaian adegan dalam iklan serta penggunaan musik dan suara dalam kedua iklan menunjukkan tidak adanya perbedaan tingkat persepsi audience yang signifikan antara dua iklan tersebut. Saran bagi penelitian selanjutnya, diharapkan penelitian ini dapat menambah dan memperluas objek penelitian dengan jumlah sampel yang lebih besar dan representative terhadap target audience iklan agar mampu memberikan gambaran secara jelas dan nyata mengenai hasil penelitian yang diinginkan. Peneliti merekomendasikan pula bagi para pemerakarsa iklan agar menggunakaan unsur humor secara hati-hati, penggunaan humor dalam iklan harus diperhatikan agar tidak merusak pemahaman audience terhadap iklan. Serta pemilihan latar yang akan digunakan dalam iklan agar mampu dipersepsi dengan baik oleh audience.
\end{abstract}

Kata-kata Kunci: Persepsi, iklan, humor, perhatian, pemahaman, ingatan

\section{COMPARISON PERCEPTION OF AUDIENCE BETWEEN CONTAIN HUMOR AND DOES NOT CONTAIN HUMOR ADVERTISEMENT}

\begin{abstract}
Advertisement is one of the substantial components in marketing communications. An advertisement will be perceived by nature's thought through the various phases. Attempts to attract the attention of consumers, advertisers insert element of humor that is identical with everything that amusing and humorous, which made as one of the appeal of the message in the ad. The author would like to see the natural differences in perception of the audience between the ads contain humor and the ads does not contain humor. For that, the ads which compared is Ramayana Department Store which contain humor, and Matahari Department Store the ads which do not contain humor. In this study, aiming to know is there any difference in the perception of the audience between advertising that contains elements of humor and does not contain the element of humor. In achieving the objectives of the study, the authors use quantitative methods in order to gain an understanding that systematic and objective. By using selective perceptions Belch and Belch based on the four stages of the process of perception are: exposure, attention, comprehension and memory against the ads. From the results of the study, the perceptions of the audience against the cast of advert, background in advertisements, a series of scenes in the ad and the use of music and sound in both ads show the absence of difference in a significant level of audience perception between two of those ads. Suggestions for further research, this research is expected to add and expand the object of research with a larger sample size and representative of the target audience rather than advertising to be able to provide a clear and concrete picture of the desired research results. Researchers also recommend for ad campaigners to use the element of humor carefully, the use of humor in advertising must be considered in order not to damage the audience's understanding of advertising. And the background selection that will be used in advertising to be able to be perceived well by the audience.
\end{abstract}

Keywords: Perception, advertisement, humor, attention, comprehension, memory

Korespondensi: Ira Yuni Mirandha, S.Ikom. Program Studi Ilmu Komunikasi, Fakultas Komunikasi dan Bisnis, Universitas Telkom, Jl. Telekomunikasi Terusan Buah Batu, Bandung 40257.Email: irayunimirandha@ gmail. com 


\section{PENDAHULUAN}

Komunikasi pemasaran menjadi inti bagaimana perusahaan memanfaatkan sebuah strategi, perencanaan, pelaksanaan dan evaluasi dalam mempertahankan atau mengembangkan perusahaan di dunia bisnis (Reza, 2016: 66). Salah satu komponen penting dalam komunikasi pemasaran adalah periklanan. Iklan merupakan cara berbiaya yang efektif guna menyebarkan pesan, entah untuk membangun preferensi, merek, atau untuk mendidik orang (Kotler, 2008: 244).

Iklan dipandang sebagai media yang paling umum digunakan untuk mengarahkan komunikasi persuasif pada konsumen, mempengaruhi perasaan, pengetahuan, kepercayaan dan sikap yang berkaitan dengan suatu produk, yang akhirnya mengarah pada upaya untuk mempengaruhi konsumen agar memiliki minat beli (Kertamukti, 2015: 21). Melalui media iklanlah, perusahaan-perusahaan mengomunikasikan segala bentuk nilai dan keunggulan produk ke dalam benak konsumen. Untuk itu, perusahaan perlu memikirkan komunikasi yang menguntungkan dengan cara memperkenalkan produk melalui iklan (Kardes dalam Mufarihah dan Triyono 2013: 21).

Untuk itu, sebagai salah satu media komunikasi visual yang sangat penting, iklan yang dibuat harus terkonsep dan memiliki pesan yang ingin disampaikan kepada konsumen. Pemasangan iklan dituntut tidak hanya menjual produk saja, tetapi iklan harus menghibur, imajinatif dan bermakna (Sudharsono 2010: 17). Maka, konsep iklan yang akan dibuat harus memiliki konten dan pesan yang jelas juga dikemas semenarik mungkin agar tidak dengan mudah ditolak oleh konsumen.

Efektivitas iklan ditentukan dari kreativitas iklan itu sendiri, sebab hal itu akan dapat menangkap perhatian konsumen dan membuat iklan menjadi makin diingat (Caples dalam Adi, 2016: 3). Menarik perhatian konsumen dapat dilakukan dengan menentukan daya tarik pesan. Salah satu daya tarik yang masih dipertanyakan para praktisi multimedia dan akademisi, tingkat keefektifan dan keberhasilannya adalah humor (Suyanto, 2004: 15).
Persaingan antar produk di pasaran mendorong produsen gencar berpromosi untuk menarik perhatian konsumen (Adi, 2016: 2). Menarik perhatian konsumen dapat dilakukan dengan menentukan daya tarik pesan. Daya tarik pesan dapat diciptakan menggunakan selebritis, humor, rasa takut, kesalahan, musik, komparatif dan seks. Salah satu daya tarik yang masih dipertanyakan para praktisi multimedia dan akademisi, tingkat keefektifan dan keberhasilannya adalah humor (Suyanto, 2004: 15).

Iklan yang menerpa calon konsumen dipersepsi dan selanjutnya mempengaruhi keputusan apa yang akan diambil dalam membeli suatu produk. Proses persepsi terjadi ketika stimuli menerpa audience, dalam hal ini, iklan menerpa audience secara sadar atau menyentuh indera manusia. Tahap selanjutnya adalah perhatian atau tahap masuknya informasi ke dalam benak audience iklan, atau dapat dikatakan ketika stimulus (iklan) dibentuk sebagai suatu informasi ke otak. Setelah informasi dibentuk selanjutnya informasi tersebut dimaknai oleh otak, dan disimpan untuk selanjutnya dipanggil kembali ketika informasi dibutuhkan otak (recall).

Diketahui dari penelitian yang telah dilakukan sebelumnya mengenai penggunaan humor pada iklan menghasilkan sesuatu yang positif. Baik terhadap asosiasi merek ataupun efektivitas iklan, yang keduanya adalah hal yang penting bagi suatu merek. Bagaimana dengan iklan yang tidak mengandung humor? Maka dari itu, dalam penelitian ini peneliti membandingkan dua buah iklan yang berbeda untuk mengetahui iklan yang seperti apa yang dipersepsi lebih baik oleh konsumen. Untuk itu, dibandingkan dua buah iklan yang berbeda dari segi penggunaan humor. Yang pertama iklan yang menampilkan humor yaitu iklan Ramayana Department Store "Keren Hak Segala Bangsa" dan yang kedua iklan yang tidak menampilkan humor didalamnya sebagai iklan pembanding yaitu Iklan Matahari Department Store. Keduanya berupaya menarik minat konsumen untuk berbelanja di Department Store terkait dalam masa menyambut Hari Raya Lebaran.

Suatu penelitian tentang periklanan majalah 
di Amerika Serikat menunjukkan bahwa sebagian besar iklan yang menggunakan humor didasarkan pada ketidakcocokan (in congruity) (Shimp, 2003: 471). Hal itu pula yang terlihat dalam iklan humor Ramayana Department Store yang memperlihatkan suatu "ketidakcocokan" dalam iklannya. Incongruity theory menurut McGhee (dalam Morreal 2009: 10) adalah sesuatu yang tidak terduga, di luar konteks, tidak pantas, tidak masuk akal, tidak logis, berlebihan dan sebagainya. Dikatakan sesuatu yang tidak terduga karena, iklan Ramayana Department Store "Keren Hak Segala Bangsa" memperlihatkan hal yang tidak terduga, seperti keadaan orang-orang yang berpose di suatu halte bus adalah ternyata para pemudik yang sedang menunggu bus.

Berupaya membedakan produknya dengan produk sejenis dan menarik perhatian konsumen, Ramayana Department Store mengkomunikasikan pesan iklan dengan cara yang berbeda, yaitu dengan daya tarik humor. Selain menggelitik, iklan Ramayana Department Store ini, dapat dengan cerdik menyampaikan pesan iklan yang diinginkan sesuai dengan hashtag yang diusung oleh Ramayana Department Store yaitu "Keren Hak Segala Bangsa".

Dalam Shimp (2003: 186) secara umum, komunikasi pemasaran yang segar (novel) adalah ide-ide yang tidak biasa, "berbeda", atau tidak dapat diprediksi. Stimulus seperti ini cenderung memperoleh perhatian yang lebih besar dibandingkan yang familiar dan rutin. Hal inilah yang ditunjukkan oleh Ramayana Department Store, sebagai salah satu merek fashion yang cukup dikenal masyarakat, Ramayana Department Store memberikan iklan yang segar dan baru dengan menggunakan humor di tengah iklan fashion retail pada umumnya.

Menyisipkan humor ke dalamnya, iklan Ramayana Department Store "Keren Hak Segala Bangsa", berusaha menyampaikan pesan dengan cara yang kreatif dan menarik. Humor yang disampaikan pun dikemas dengan semenarik mungkin dengan penggunaan materi "keseharian masyarakat" yang juga menjadi target pasar Ramayana Department Store.
Berbeda dengan Ramayana Department Store, iklan Matahari Department Store, yang juga hadir di pertengahan tahun, tidak menggunakan humor dalam iklannya. Suasana kedamaian nampak dalam iklan Matahari Department Store ini. Mulai dari model yang mengenakan pakaian dari Matahari Department Store tersenyum dan melipat tangan di dada seolah-olah meminta maaf nampak di scene iklan tersebut.

Kedua iklan yang dikeluarkan oleh masing-masing Department Store dalam rangka menyambut Lebaran, telah mengusung konsep, tema dan idenya masing-masing. Satu iklan menampilkan humor yaitu iklan Ramayana Department Store dan satu iklan lagi tidak menampilkan humor di dalamnya yaitu Iklan Matahari Department Store. Keduanya berupaya menarik minat konsumen untuk berbelanja di Department Store terkait di tengah persaingan yang makin kompetitif. Namun iklan yang manakah yang dipersepsi lebih baik oleh audience?

Merujuk pada penjelasan awal, maka menarik bagi peneliti untuk meneliti mengenai Perbandingan Persepsi Audience Antara Iklan yang Mengandung Humor dan Tidak Mengandung Humor (Studi Eksperimental pada Iklan Ramayana Department Store dan Iklan Matahari Department Store).

\section{METODE PENELITIAN}

Dalam penelitian ini, paradigma yang digunakan adalah paradigma positivistik untuk meneliti persepsi audience antara iklan yang mengandung humor yaitu Iklan Ramayana Department Store dan iklan yang tidak mengandung humor yaitu Iklan Matahari Department Store. Peneliti memandang persepsi audience dapat diukur dan diamati secara objektif sehingga peneliti mendapatkan pemahaman yang sistematis. Untuk menguji hipotesis dalam penelitian ini, peneliti mengumpulkan data menggunakan instrumen penelitian yang didasarkan pada pengukuran persepsi audience terhadap terpaan iklan, perhatian terhadap iklan, pemahaman terhadap iklan dan ingatan terhadap iklan yang dijelaskan 
oleh Belch \& Belch (2010: 120).

Metode kuantitatif yang digunakan adalah metode penelitian eksperimen. Menurut Sugiyono (2014: 36) metode eksperimen adalah metode penelitian yang digunakan untuk mencari pengaruh treatment tertentu (perlakuan) dalam kondisi yang terkontrol (laboratorium). Dengan demikian metode penelitian eksperimen dapat diartikan sebagai metode penelitian yang digunakan untuk mencari pengaruh perlakuan tertentu terhadap yang lain dalam kondisi yang dikendalikan (Sugiyono, 2014: 334). Perlakuan diberikan pada permulaan dan kemudian untuk mengetahui seberapa jauh hasilnya dilaksanakan pengukuran pada akhir kegiatan atau kejadian (Yusuf, 2014: 180).

Dalam hal ini, penelitian dilakukan pemberian treatment, dengan memperlihatkan kedua video iklan tersebut, yaitu iklan dengan humor (Iklan Ramayana Department Store) dan iklan tanpa humor (Iklan Matahari Department Store) kepada 100 responden, untuk selanjutnya mengisi kuisioner yang telah diberikan oleh peneliti. Treatment dilakukan dengan penyeragaman terpaan kepada sampel penelitian. Untuk selanjutnya dilakukan posttest oleh peneliti. Sehingga dengan melakukan treatment terhadap subjek penelitian maka diharapkan akan mampu memahami tingkah laku manusia secara objektif dari kegiatan pengukuran secara terkendali melalui penelitian eksperimental.

Dalam penelitian ini, yang menjadi objek penelitian atau objek yang dijadikan sebagai bahan pengamatan adalah persepsi audience terhadap iklan. Dalam hal ini, persepsi khalayak iklan mengenai dua iklan yang berbeda yaitu dengan membandingkan iklan yang mengandung humor yaitu iklan Ramayana Department Store "Keren Hak Segala Bangsa" dengan iklan yang tidak mengandung humor, yaitu iklan Matahari Department Store.

Untuk subjek penelitian dalam penelitian ini adalah para khalayak iklan tersebut atau dapat dikatakan, siapa saja yang terterpa iklan tersebut. Hal ini pulalah yang menjadi dasar pemilihan penelitian eksperimental dalam penelitian ini. Mengingat bahwasannya, siapa saja dapat terterpa iklan ini.
Penelitian membutuhkan sampel karena menurut Miles dan Huberman (dalam Anita, 2008: 29), peneliti tidak bisa mempelajari semua orang, pada semua tempat, yang melakukan semua hal. Pada penelitian yang sebelumnya telah dilakukan Anita dalam "Pengaruh Persepsi Iklan dengan Unsur Humor terhadap Tingkat Asosiasi Merek $\mathrm{Nu}$ Green Tea sebagai Teh Kesehatan" ditentukan jumlah sampel sebanyak 100 responden sebagai sampel.

Didasari pada hal itulah peneliti menentukan jumlah responden dalam penelitian ini sebanyak 100 responden dengan teknik penarikan sampel dengan quota sampling. Quota sampling adalah teknik pengambilan sampel dengan menentukan jumlah sampel terlebih dahulu baru mengumpulkan data (Taniredja dan Mustafidah, 2011: 38). Hal ini dipilih mengingat bahwa penelitian ini bersifat eksperimental dengan rancangan one shot case study yaitu dengan pemberian stimulus pada responden dan mengukurnya dengan posttest. Dirasa sulit bagi peneliti melakukan penelitian eksperimental ini pada seluruh populasi. Maka peneliti membatasi jumlah responden sebanyak 100 responden didasari pada penelitian yang sebelumnya telah dilakukan.

Untuk menganalisis data dalam penelitian yang ingin mengetahui perbandingan persepsi audience antara dua iklan yang berbeda ini maka akan diuji menggunakan uji paired test (Santosa dan Hidayat, 2014: 245) yang akan diuji dengan rumus berikut:

Jika salah satu simpangan baku tidak diketahui, statistik uji yang digunakan adalah:

$$
\mathrm{t}=\frac{\overline{x_{1}}-\overline{x_{2}}}{s \sqrt{\frac{1}{n_{1}}+\frac{1}{n_{2}}}} \text { dengan } s^{2}=\frac{\left(n_{1}-1\right) s_{1}^{L}+\left(n_{2}-1\right) s_{2}^{<}}{n_{1}+n_{2}-2}
$$

dengan kriteria uji taraf nyata sebesar $\alpha$.

Terima $\mathrm{H}_{0}$ jika

$$
-t_{1-1 / 2^{\alpha}}<t<t_{1-1 / 2^{\infty}}
$$

tolak $\mathrm{H}_{0}$ dalam hal lainnya, dimana nilai

$$
t_{1-1 / 2 \propto}
$$

didapat dari tabel distribusi student dengan dk $($ derajat kebebasan $)=\left(\mathrm{n}_{1}+\mathrm{n}_{2}-2\right)$. Dengan kriteria uji: Tolak $\mathrm{H}_{0}$ jika $\mid \mathrm{t}$ hitung $\mid \geq \mathrm{t}$ tabel. 


\section{HASIL DAN PEMBAHASAN}

Menurut Ambler et. al. (dalam Ferrinadewi 2008: 2) aktivitas pemasaran yang dilakukan perusahaan harus mampu mempengaruhi alam pikir konsumen. Hal inilah yang dibahas dalam penelitian ini yaitu mengenai bagaimana alam pikir konsumen mempersepsi antara iklan yang mengandung humor dan tidak mengandung humor.

Dalam penelitian ini dilakukan metode penelitian eksperimental kepada 100 responden yang bersedia untuk diberikan perlakuan. Dalam hal ini, penelitian dilakukan dengan treatment memperlihatkan kedua video iklan tersebut.
Pada 100 responden diperlihatkan iklan dengan humor yaitu iklan Ramayana Department Store yang dapat dilihat pada gambar 1.

Selanjutnya responden mengisi kuisioner Iklan Ramayana Department Store dengan jumlah pertanyaan sebanyak 48 pertanyaan. Setelah selesai dengan iklan pertama selanjutnya responden diperlihatkan iklan tanpa humor yaitu Iklan Matahari Department Store yang dapat dilihat pada gambar 2. Dengan jumlah pertanyaan sebanyak 45 pertanyaan. Treatment yang diberikan dengan melakukan penyeragaman terpaan kepada sampel penelitian yaitu masing-masing sebanyak satu kali menonton iklan-iklan tersebut.

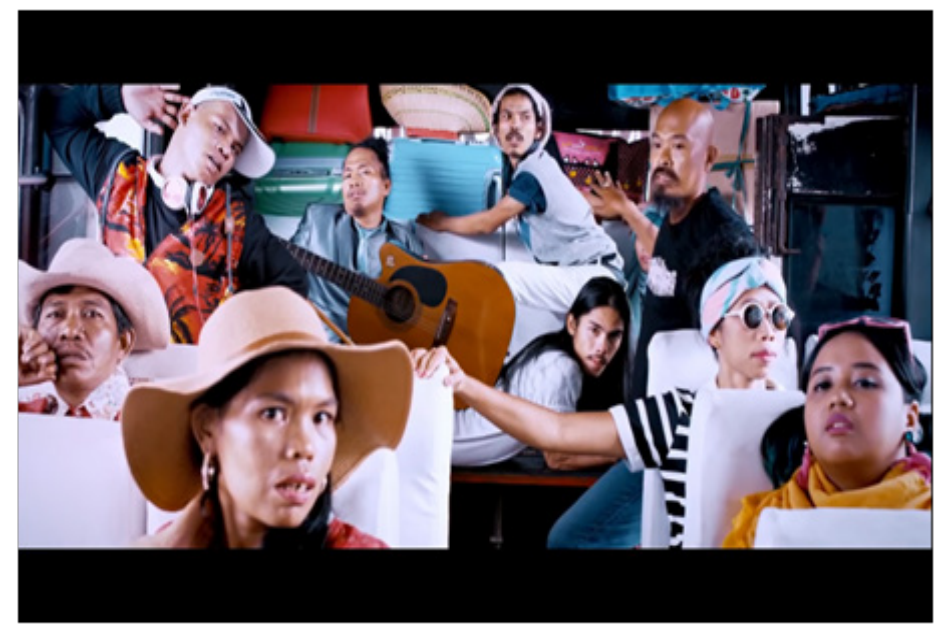

Sumber: Youtube, 2016

Gambar 1 Tampilan Iklan Ramayana Department Store

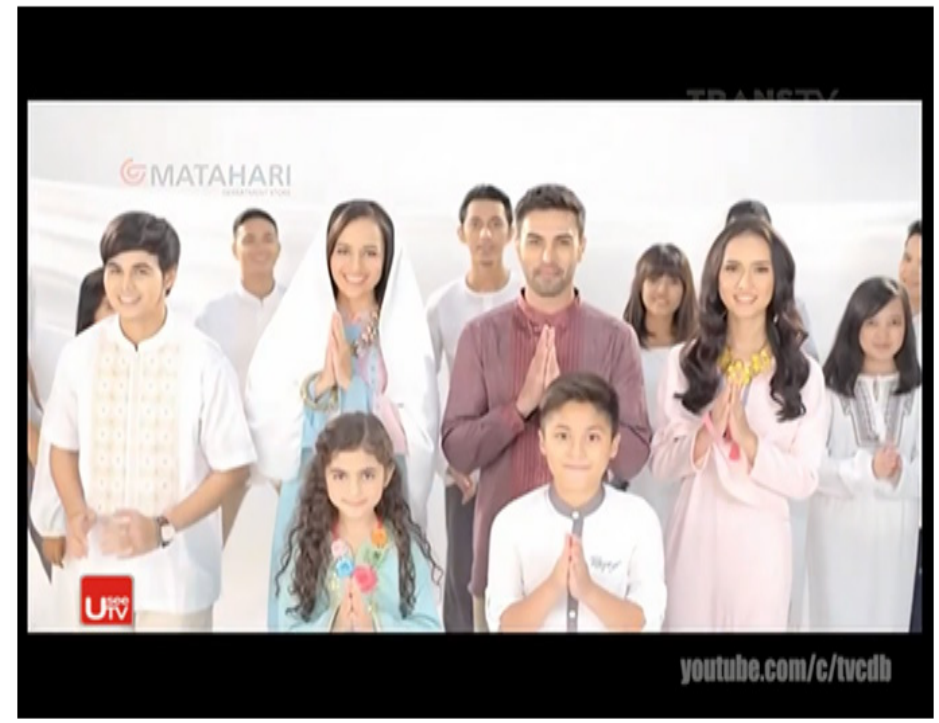

Sumber: Youtube, 2016

Gambar 2 Tampilan Iklan Matahari Department Store 
Persepsi adalah pemberian makna pada stimulus inderawi (sensory stimuli). Merupakan proses yang digunakan oleh konsumen untuk memilih, mengorganisasi dan menginterpretasi informasi mengenai suatu produk yang berasal dari iklan, menurut Abideen dan Saleem (dalam Hakim dan Susilowati, 2011: 539). Dalam penelitian ini persepsi audience antara dua buah iklan diukur dan dibandingkan dengan menggunakan instrumen kuisioner yang telah dirancang oleh peneliti. Peneliti ingin mengetahui apakah penggunaan humor dalam iklan mampu meningkatkan persepsi audience dibandingkan dengan iklan non humor. Kedua iklan yang diperbandingkan antara lain: iklan yang mengandung humor (Iklan Ramayana Department Store) dan iklan yang tidak mengandung humor (Iklan Matahari Department Store).

Persepsi bersifat individual. Kotler dan Keller dalam (Pramitasari, Indriana, \& Ariati, 2011) mengatakan bahwa persepsi sangat beragam antara individu satu dengan yang lain yang mengalami realitas yang sama.

Menurut Arikunto (2010: 269) dari jawaban yang diberikan responden kemudian disusun kriteria penelitian untuk setiap butir pertanyaan berdasarkan persentase dengan langkah-langkah sebagai berikut: (1) Nilai kumulatif adalah jumlah dari setiap pernyataan yang merupakan jawaban dari 100 responden. (2) Persentase adalah nilai kumulatif item dibagi dengan nilai frekuensinya dikalikan 100\%. (3) Menghitung jumlah kumulatif terbesar dan terkecil. Jumlah responden adalah 100 orang dan nilai skala pengukuran terbesar adalah 1 (satu) dan skala pengukuran terkecil adalah 0 (nol). Jadi, jumlah kumulatif terbesar adalah $100 \times 1=100$ dan jumlah kumulatif terkecil adalah $100 \times 0=0$. (4) Menentukan nilai persentase terbesar dan terkecil. Nilai persentase terbesar $=100100 \mathrm{x}$ $100 \%=100 \%$ dan nilai persentase terkecil $=$ $0100 \times 100 \%=0 \%$. (5) Nilai rentangan adalah $100 \%-0 \%=100 \%$. Jika nilai rentangan dibagi 2 (dua) skala pengukuran, maka diperoleh nilai interval persentase sebesar 50\% sehingga diperoleh kriteria interpretasi skor yang ditunjukkan pada tabel 1 .

Dengan persentase sebesar 1\%-50\%
Tabel 1 Tingkat Persepsi Audience

\begin{tabular}{cc}
\hline $1 \%-50 \%$ & $51 \%-100 \%$ \\
\hline BURUK & BAIK \\
\hline
\end{tabular}

Sumber: Arikunto (2010: 269) dan Hasil Olahan (Penulis, 2017)

\section{Tabel 2 Rekapitulasi Data Persentase Per Indikator Antara Iklan Ramayana Department Store dan Iklan Matahari Department Store}

\begin{tabular}{ccc}
\hline Indikator & $\begin{array}{c}\text { Iklan } \\
\text { Ramayana } \\
\text { Department } \\
\text { Store }\end{array}$ & $\begin{array}{c}\text { Iklan } \\
\text { Matahari } \\
\text { Department } \\
\text { Store }\end{array}$ \\
\hline Perhatian & $69 \%$ & $67 \%$ \\
Pemahaman & $63 \%$ & $70 \%$ \\
Ingatan & $70 \%$ & $67,8 \%$ \\
\hline
\end{tabular}

Sumber: Data olahan penulis, 2017

dikategorikan sebagai tingkat persepsi audience yang buruk karena dianggap iklan hanya mampu mempersepsi sebagian kecil unsur dalam iklan, sedangkan persentase 51\%-100\% dikategorikan sebagai tingkat persepsi audience yang baik. Angka tersebut dianggap sebagai persepsi yang baik karena angka menunjukkan tingkat persepsi audience yang dominan mampu mempersepsi iklan, atau dengan kata lain mampu mempersepsi hampir sebagian besar iklan dengan baik. Dari keseluruhan hasil pengukuran terhadap tiap pernyataan per indikator dalam kuisioner dapat dilihat dalam tabel 2 .

Dari rekapitulasi data persentase per indikator pada tabel 2, dapat diketahui bahwa besarnya tingkatan perhatian audience pada iklan yang mengandung humor yaitu iklan Ramayana Department Store sedikit lebih besar jika dibandingkan dengan iklan yang tidak mengandung humor, yaitu sebesar $69 \%$ untuk Ramayana Department Store dan Matahari Department Store 67\%. Sedangkan pada 
indikator pemahaman terhadap kedua iklan, tingkat pemahaman audience akan iklan yang tidak mengandung humor jauh lebih besar yaitu $70 \%$ jika dibandingkan dengan pemahaman terhadap iklan yang mengandung humor yang hanya dipersepsi baik sebesar 63\%. Terdapat selisih cukup besar antara pemahaman kedua iklan yaitu sebesar 7\%. Selanjutnya, pada hasil pengukuran akan ingatan audience terhadap kedua iklan hanya terdapat selisih $2,2 \%$ antara iklan mengandung humor yang lebih tinggi yaitu sebesar $70 \%$ sedangkan iklan tanpa humor dengan angka $67,8 \%$.

Dapat disimpulkan bahwa tingkat persepsi audience terhadap kedua iklan menunjukkan kategori kedua iklan tersebut dapat dipersepsi dengan baik. Sedangkan dari dimensi yang diukur, tingkat perhatian audience akan iklan Ramayana Department Store lebih tinggi jika dibandingkan dengan iklan Matahari Department Store. Namun, iklan non humor Matahari Department Store jauh lebih baik dipahami audience dibandingkan dengan iklan Ramayana Department Store Sedangkan dalam ingatan audience akan kedua iklan, tingkat ingatan audience terhadap iklan Ramayana lebih besar dibandingkan dengan iklan Matahari Department Store.

Tingkat rerata dan persentase persepsi audience secara keseluruhan dapat dilihat dalam tabel 3. Dapat diketahui dari tabel 3 besarnya nilai rerata total daripada persepsi audience terhadap iklan Ramayana Department Store adalah sebesar 0,673 atau sebesar 67\% sedangkan nilai rerata total persepsi audience terhadap iklan Matahari Department Store sebesar 0,6827 atau sebesar 68,27\%. Dari kedua iklan yang dibandingkan terdapat perbedaan yang tidak begitu signifikan sebesar 0,97\%. Yang dapat diartikan sebagai adanya sedikit perbedaan persepsi audience antara iklan yang mengandung humor dan tidak mengandung humor namun perbedaan persepsi tersebut tidaklah terlalu signifikan karena hanya berbeda

Tabel 3 Rekapitulasi Data Mean dan Persentase Persepsi Audience antara Iklan Ramayana Department Store dan Iklan Matahari Department Store

Iklan Ramayana

Department Store
Iklan Matahari

Department Store
Tingkat Rerata Persepsi Audience

Tingkat Persentase Persepsi Audience

Selisih Tingkat Persentase Persepsi Audience
0.673

$67 \%$
0.6827

$68,27 \%$

$0.97 \%$

Sumber: Data olahan penulis, 2017

Tabel 4 Hasil Rerata Persepsi Audience

\begin{tabular}{llllll}
\hline \multicolumn{5}{c}{ Paired Samples Statistics } \\
\hline \multirow{2}{*}{ Pair 1 } & Mean & $\mathrm{N}$ & Std. Deviation & Std. Error Mean \\
\cline { 3 - 6 } & Ramayana & 68.267 & 100 & 24.63437 & 2.46344 \\
& 67.333 & 100 & 21.25114 & 2.12511 \\
\hline
\end{tabular}

Sumber: Data diolah oleh peneliti dengan (SPSS) 21.0 for windows (2017) 
$0,97 \%$.

Persepsi berlangsung dalam setiap kegiatan komunikasi baik yang melibatkan orang lain maupun intra personal. Itu dikarenakan persepsi merupakan hasil dari kontak langsung indera kita dengan berbagai rangsangan baik yang berasal dari lingkungan fisik maupun dari manusia. Persepsi juga berlaku bagi komunikan atau audience televisi dengan tayangan televisi (Arriandi, 2014).

Tabel 4 menunjukkan hasil perhitungan rata-rata persepsi audience dengan jumlah responden sebanyak 100 . Hasil perhitungan menggunakan software SPSS 21.0 for windows.

Sebanyak 100 responden yang mengisi kuisioner perbandingan persepsi antara iklan mengandung humor dan tidak mengandung humor didapati rerata sebesar 68,267 untuk rerata tingkat persepsi audience untuk iklan tanpa humor, Matahari Department Store dan rerata 67,333 untuk tingkat persepsi audience untuk iklan dengan humor, Ramayana Department Store. Untuk selanjutnya diketahui standar deviasi dan standar error mean antara kedua rerata dengan perhitungan menggunakan software SPSS 21.0 for windows.

Hasil perhitungan rerata yang telah dilakukan, selanjutnya adalah menghitung $\mathrm{t}$ hitung menggunakan software SPSS 21.0 for windows. Tabel 5 menjabarkan hasil perhitungan persepsi audience terhadap kedua iklan yang dibandingkan, dihitung menggunakan software SPSS 21.0 for windows.

Berdasarkan uji beda rata-rata dengan menggunakan paired $\mathrm{t}$ test, dilakukan untuk melihat perbandingan persepsi audience antara iklan Matahari Department Store dengan iklan Ramayana Department Store. Dengan hipotesis sebagai berikut, hipotesis yang pertama $\mathrm{H}_{0}: \mu_{1}=$ $\mu 2$, tidak terdapat perbedaan persepsi audience antara iklan Matahari Department Store dengan iklan Ramayana Department Store dan hipotesis kedua $\mathrm{H} 1: \mu_{1} \neq \mu_{2}$, terdapat perbedaan persepsi audience antara iklan Matahari Department Store dengan iklan Ramayana Department Store. Statistik uji yang digunakan adalah

$$
\mathrm{t}=\frac{\overline{x_{1}}-\overline{x_{2}}}{\sqrt[s]{\frac{1}{n_{1}}+\frac{1}{n_{2}}}} \text { dengan } s^{2}=\frac{\left(n_{1}-1\right) s_{1}^{2}+\left(n_{2}-1\right) s_{2}^{2}}{n_{1}+n_{2}-2}
$$

\section{Tabel 5 Uji Paired T-Test}

Paired Samples Test

Paired Differences

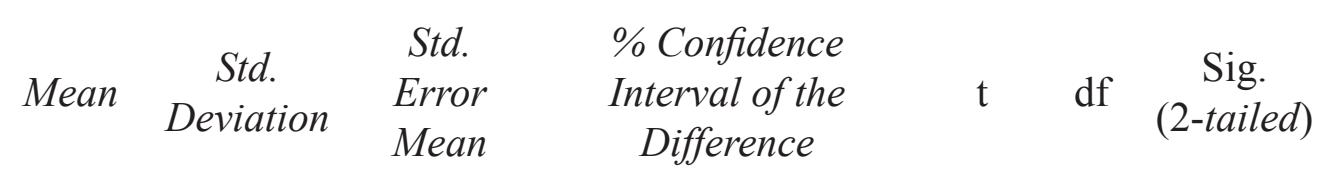

2. 19685 Lower Upper

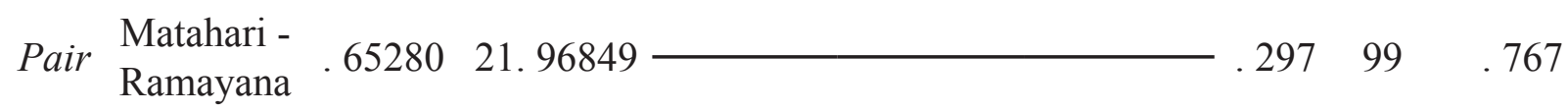

$-3.70622 \quad 5.01182$

Sumber: Data diolah oleh peneliti dengan (SPSS) 21.0 for windows (2017) 
Tabel 6 Hasil T-Hitung

\begin{tabular}{ccccccc}
\hline Perbandingan & Rata-Rata & thitung & df & t tabel & $\begin{array}{c}\text { p-value } \\
\text { (sig) }\end{array}$ & Keterangan \\
\hline $\begin{array}{c}\text { Matahari } \\
\text { Department } \\
\text { Store }\end{array}$ & 68,267 & & & & & \\
\hline $\begin{array}{c}\text { Ramayana } \\
\text { Department } \\
\text { Store }\end{array}$ & 67,333 & 0,297 & 99 & 1,984 & 0,767 & $\mathrm{H}_{0}$ diterima \\
\hline
\end{tabular}

Sumber : Data diolah oleh peneliti dengan (SPSS) 21.0 for windows(2017)

dengan kriteria uji taraf nyata sebesar $\alpha$. Terima $\mathrm{H}_{0} \mathrm{jika}$

$$
-t_{1-1 / 2^{\alpha}}<t<t_{1-1 / 2^{\alpha}}
$$

tolak $\mathrm{H}_{0}$ dalam hal lainnya, dimana nilai

$$
t_{1-1 / 2^{\alpha}}
$$

didapat dari tabel distribusi student dengan $\mathrm{dk}$ (derajat kebebasan) $=\left(\mathrm{n}_{1}+\mathrm{n}_{2}-2\right)$. Dengan kriteria uji: Tolak $\mathrm{H}_{0}$ jika $\mid \mathrm{t}$ hitung $\mid \geq \mathrm{t}$ tabel. Hasilnya ditunjukkan oleh tabel 6 .

Berdasarkan hasil perhitungan diperoleh $\mathrm{t}$ hitung lebih kecil dari t tabel dengan p-value $\geq 0,05$. Karena nilai $t$ hitung $(0,297)<$ nilai $t$ tabel $(1,984)$, maka $\mathrm{H}_{0}$ diterima. Oleh karena itu, dapat disimpulkan bahwa tidak terdapat perbedaan signifikan antara iklan Ramayana Department Store dan Matahari Department Store.

Tabel 6 menunjukkan bahwa rata-rata iklan Matahari Department Store sebesar 68,267, sedangkan rata-rata iklan Ramayana Department Store sebesar 67,333. Sehingga rata-rata iklan Matahari Department Store tidak jauh berbeda dengan iklan Ramayana Department Store.

Faktanya, penggunaan humor dalam iklan adalah topik yang kompleks yang telah dipelajari oleh pengiklan dalam beberapa penelitian selama 25 tahun terakhir (Weinberger dan Gulas, 1992: 35). Berdasarkan pada hasil survei yang dipaparkan Suyanto (2004: 15) menjelaskan bahwa pemakaian humor dianggap sangat efektif untuk membuat orang-orang memperhatikan iklan dan hal ini terbukti dalam hasil penelitian ini. Bahwasanya terlihat dari angka yang ditunjukkan pada hasil penelitian ini menunjukkan tingkat perhatian audience terhadap iklan yang mengandung humor lebih tinggi dibandingkan dengan iklan yang tidak mengandung humor.

Dalam penelitian akademis lainnya juga telah menunjukkan bahwa iklan yang menggunakan humor lebih menarik perhatian dan menimbulkan keinginan yang besar dari iklan yang tidak menggunakan humor Speck (dalam Febrianto dan Sukirno, 2015: 3). Hal ini juga memperkuat penggunaan humor sangat efektif dalam menarik perhatian audience. Hanya saja data dari penelitian ini tidak dapat membuktikan apakah penggunaan humor menimbulkan keinginan yang lebih besar dibandingkan dengan iklan yang tidak menggunakan humor.

Tak hanya itu, efektivitas suatu iklan ditentukan dari kreativitas iklan itu sendiri, sebab hal itu akan dapat menangkap perhatian konsumen dan membuat iklan jadi makin diingat (Moriarty dalam Adi, 2016: 3). Terbukti dari hasil penelitian, diketahui angka perhatian dan ingatan audience terhadap iklan humor lebih tinggi dibandingkan dengan iklan yang tanpa humor. Keefektifan iklan adalah sejauh mana sebuah iklan mencapai tujuan yang sangat dibutuhkan dalam menangkap mata dan pikiran target (Thiyagarojan, Shanthi dan Naresh, 2012: 455).

Selain itu, dari hasil penelitian dapat 
diketahui angka terhadap penggunaan latar yang digunakan dalam iklan mampu dipersepsi dengan baik dalam iklan dengan rerata sebesar $86,67 \%$. Hal tersebut dapat diartikan sebagai pemilihan dan penggunaan latar atau setting dalam iklan mampu diperhatikan, dipahami dan diingat dalam benak khalayak dengan baik.

Dari penelitian yang dilakukan oleh (Jati \& Herlina, 2013) mengemukakan bahwa keaktifan audiens dalam menggunakan media akan menghadirkan tanggapan setelah pemakaian media, apakah mereka puas atau tidak. Sejalan dengan kelima asumsi yang telah dijabarkan sebelumnya, khususnya asumsi yang menyampaikan bahwa khalayak yang memilih media dan menggunakannya berdasarkan kebutuhan mereka dan kemudian memberikan penilaian atas penggunaan media tersebut.

Seperti halnya pada hasil penelitian persepsi pada iklan dengan unsur humor dilakukan oleh Anita menunjukkan bahwa iklan dengan unsur humor mampu mempengaruhi tingkat asosiasi merek $\mathrm{Nu}$ Green Tea sebagai teh kesehatan (Anita, 2008: 81). Begitu juga dengan penelitian yang dilakukan oleh Ericho Prasetya Adi, mengenai pengaruh penggunaan kreativitas iklan, unsur humor dan kualitas pesan iklan pada iklan televisi produk Aqua terhadap efektivitas iklan, yang menunjukkan terdapat pengaruh positif dari kreativitas iklan, unsur humor dan kualitas pesan terhadap efektivitas iklan. Dalam hal ini penggunaan kreativitas iklan, unsur humor dan kualitas pesan menimbulkan perhatian dan sikap terhadap iklan yang positif.

Dari hasil penelitian-penelitian di atas, diketahui penelitian yang dilakukan mengenai penggunaan humor pada iklan menghasilkan sesuatu yang positif. Dari hasil penelitian ini, penggunaan humor dalam iklan, terbukti mampu menarik perhatian audience serta meningkatkan ingatan akan sebuah iklan.

Dalam hal ini, perhatian dan ingatan audience akan iklan humor lebih tinggi dibandingkan dengan iklan yang tanpa humor. Namun saja, sesuai dengan hasil penelitian (Weinberger dan Madden, 1984: 28) yang mengatakan penggunaan humor dapat membahayakan pemahaman terhadap iklan benar adanya.
Terlihat dari hasil penelitian, pemahaman audience terhadap penggunaan humor dalam iklan menunjukkan angka yang rendah dibandingkan dengan iklan yang tanpa humor, dapat diasumsikan penggunaan humor dalam iklan dapat menurunkan tingkat pemahaman audience terhadap sebuah iklan. Secara keseluruhan, menurut hasil penelitian yang dituliskan oleh Suyanto (2004: 15) penggunaan humor dalam iklan dianggap tidak merugikan secara keseluruhan, dalam hal ini kaitannya adalah penggunaan humor dalam iklan Ramayana Department Store memiliki tingkat perhatian dan ingatan audience yang lebih tinggi dibandingkan dengan iklan Matahari Department Store.

\section{SIMPULAN}

Berdasarkan hasil penelitian yang telah dilakukan mengenai perbandingan persepsi audience antara dua buah iklan yang dibandingkan yaitu iklan mengandung humor, Ramayana Department Store dan iklan non humor, Matahari Department Store maka diperoleh hasil yang menjawab rumusan masalah dalam penelitian ini yaitu, tidak adanya perbedaan persepsi audience yang cukup signifikan antara iklan yang mengandung humor (Ramayana Department Store) dan pada iklan yang tidak mengandung humor (Matahari Department Store). Dikarenakan, bahwa persentase iklan Matahari Department Store sebesar 68,27\%, sedangkan persentase iklan Ramayana Department Store sebesar 67\%. Sehingga rata-rata iklan Matahari Department Store tidak jauh berbeda dengan iklan Ramayana Department Store dengan selisih persentase sebesar $0,97 \%$. Untuk itu, penulis merekomendasikan untuk menggunakaan unsur humor secara hati-hati, penggunaan humor dalam iklan harus diperhatikan agar tidak merusak pemahaman audience terhadap iklan.

Saran bagi penelitian selanjutnya, diharapkan penelitian ini dapat menambah dan memperluas objek penelitian dengan jumlah sampel yang lebih besar dan representative terhadap target audience daripada iklan agar mampu memberikan gambaran secara jelas dan 
nyata mengenai hasil penelitian yang diinginkan. Selain itu, peneliti berharap penelitian selanjutnya menggunakan pendekatan kualitatif guna memperdalam mengenai persepsi antara iklan mengandung humor dan tidak mengandung humor. Untuk penelitian selanjutnya, agar dapat dilakukan pengukuran perbedaan persepsi audience terhadap daya tarik pesan lainnya.

Selain itu, peneliti merekomendasikan pula bagi para pemerakarsa iklan agar menggunakaan unsur humor secara hati-hati, penggunaan humor dalam iklan harus diperhatikan agar tidak merusak pemahaman audience terhadap iklan. Selain itu peneliti menyarankan untuk pengiklan agar dengan tepat dalam pemilihan latar yang akan digunakan dalam iklan karena sesuai dengan hasil penelitian, penggunaan latar yang tepat mampu dipersepsi sangat baik dalam iklan.

\section{DAFTAR PUSTAKA}

Adi, E. P. (2016). Pengaruh kreativitas iklan, unsur humor, dan kualias pesan iklan terhadap efektivitas iklan televisi aqua versi "ada aqua". Yogyakarta: Fakultas Ekonomi Universitas Negeri Yogyakarta. Diakses pada 7 Agustus 2016

Anita, D. M. (2008). Pengaruh persepsi pada iklan dengan unsur humor terhadap tingkat asosiasi merek nu green tea sebagai teh kesehatan (studi kasus iklan televisi nu green tea versi nyanyian jepang "so ra no shita dee ookikunate”). Depok: Fakultas Ilmu Sosial dan Politik Universitas Indonesia. Diakses pada 19 September 2016

Arikunto, S. (2010). Prosedur penelitian suatu pendekatan praktik. Jakarta: Rineka Cipta

Arriandi, C. (2014 ). Persepsi remaja terhadap sosialisasi pacaran sehat sebagai pendidikan seks oleh crisis center cahaya mentari surabaya. Jurnal e-Komunikasi Universitas Kristen Petra, 1-9

Febrianto, S. \& Sukirno, I. (2015). Pengaruh penggunaan humor dalam iklan terhadap brand recognition (studi iklan televisi djarum 76 seri "jin" pada mahasiswa fakultas ekonomi universitas atma jaya yogyakarta. Yogyakarta: Fakultas Ekonomi Universitas Atma Jaya Jogjakarta. Diakses pada 13 September 2016

Ferrinadewi, E. (2008). Merek dan psikologi konsumen. Yogyakarta: Graha Ilmu

Hakim, R. T. \& Susilowati, C. (2011). Pengaruh persepsi iklan, kesadaran merek, citra merek terhadap sikap pada merek dan keputusan pembelian (studi pada produk pestisida merek sidamethrin 50 ec). Malang: Fakultas Ekonomi dan Bisnis Universitas Brawijaya, diakses pada 13 September 2016

Jati, R. P., \& Herlina, M. (2013). Hubungan antara radio streaming dengan persepsi dan kepuasan audiens di pt. mnc skyvision jakarta. Jurnal Komunikasi ASPIKOM, Volume 2, 589-602

Kertamukti, R. (2015). Strategi kreatif dalam periklanan. Bandung: Raja Grafindo Persada

Kotler, P. \& Keller, K. L. (2008). Manajemen pemasaran. Edisi Kedua Belas, Indonesia: Macanan Jaya Cemerlang

Morreal,J.(2009). Comic relief: a comprehensive philosophy of humor. Singapore: Wiley Blackwell, A John Wiley and Sons, Ltd., Publication

Mufarihah, H. \& Triyono. (2013). Dampak periklanan terhadap minat beli pada $h p$ samsung galaxy (studi eksplorasi pengguna hp samsung galaxy di semarang. Semarang: Fakultas Ekonomi Universitas Muhammadiyah Semarang. Diakses pada 13 September 2016

Pramitasari, A., Indriana, Y., \& Ariati, J. (2011). hubungan antara persepsi terhadap metode pembelajaran kontekstual dengan motivasi belajar biologi siswa kelas xi ipa. Jurnal Psikologi Undip Vol. 9, 92-102

Reza, F. (2016). Strategi promosi penjualan online lazada.co.id. Jurnal Kajian Komunikasi (JKK). Volume 4, Nomor 1

Santosa \& Hidayat. (2014). Riset terapan: teori dan aplikasi. Jakarta: Globalstat Solusi Utama

Shimp, T. (2003). Periklanan promosi aspek tambahan komunikasi pemasaran Terpadu. Jakarta: Erlangga

Sudharsono, W. (2010). Pengaruh iklan dengan unsur humor di televisi terhadap minat beli konsumen (studi kasus terhadap iklan rokok "starmild" di fakultas ekonomi universitas sebelas maret surakarta. Surakarta: 
Fakultas Ekonomi Universitas Sebelas Maret. Diakses pada 7 Agustus 2016

Sugiyono. (2014). Metode penelitian manajemen: pendekatan, kuantitatif, kualitas, kombinasi, penelitian tindakan. Yogyakarta: Alfabeta

Suyanto. M. (2004). Aplikasi desain grafis untuk periklanan. Yogyakarta: Andi Yogyakarta

Taniredja. (2011). Model-model pengembangan inovatif. Bandung: Alfabeta

Tukiran, T. \& Mustafidah, H. (2011). Penelitian kuantitatif; sebuah pengantar. Jakarta: Alfabeta

Thiyagarajan, S., Shanthi, P., \& Naresh, G.
(2012). Viewers's perception of tv ads: the role of sex appeal. Psychology Research. ISSN 2159-5542 August 2012 Vol. 2 No. 8

Weinberger, M. G. \& Gulas, C. S. (1992). The impact of humor in advertising: a review. Journal of Advertising. Volume XXI, December 1992. No. 4

Weinberger, M. G. \& Madden, T. J. (1984). Humor in advertising: a practicioner review. August/September 1984. Volume 24, No. 4

Yusuf, M.(2014). Metodepenelitian: kuantitatif, kualitatif dan penelitian gabungan. Jakarta, Prenadamedia Group 